Arab World English Journal (AWEJ) Special Issue on Covid 19 Challenges April 2021

DOI: https://dx.doi.org/10.24093/awej/covid.6

\title{
Devices and Platforms Used in Emergency Remote Learning and Teaching During Covid19: A Case of English Major Students in Saudi Arabia
}

\author{
Mishal H. Al Shammari \\ English Language and Translation \\ College of Languages and Translation \\ King Saud University, Riyadh, Saudi Arabia \\ Email: almoued@gmail.com
}

Received: 2/4/2021

Accepted: $3 / 24 / 2021$

Published: 4/26/2021

\section{Abstract}

This study investigates the experiences of English major students at the College of Language and Translation (COLT) in King Saud University, Saudi Arabia, with Emergency Remote Learning and Teaching (ERLT) during the Covid-19 crisis. It focuses on the students' preferences for devices and platforms, and gender differences influencing their choices. The study is of significance because it considers the student-centered learning approaches. The paper also seeks to answer the question as to the factors that lead students to make their preferences for the online teaching tools and devices. A total of 150 students, both men, and women, participated in the study. An online survey was carried out in the form of questionnaires to elicit their responses. The results showed that laptop computers were the dominant devices students used and preferred. They also revealed that the Zoom platform came first in students' preferences, followed by Blackboard. Also, the findings showed that although participants used smartphones in their ERL, they did not recommend it, and it came last compared to laptops, tablets, and desktop computers in their order of preference. Gender differences existed in preferences to desktops and tablets in ERL. Another gender difference existed in preferences to platforms. Women students preferred Blackboard to Zoom while men students expressed the opposite.

Keywords: Blackboard and Zoom, devices and platforms, emergency remote learning and teaching, English major students, gender differences, Saudi universities.

Cite as: Al Shammari, M. H. (2021). Devices and Platforms Used in Emergency Remote Learning and Teaching During Covid-19: A Case 0f English Major Students in Saudi Arabia. Arab World English Journal (AWEJ) Special Issue on Covid 19 Challenges (1) 80- 94

DOI: https://dx.doi.org/10.24093/awej/covid.6 
Arab World English Journal (AWEJ) Special Issue on Covid 19 Challenges April 2021

Devices and Platforms Used in Emergency Remote Learning

Al Shammari

\section{Introduction}

The year 2020 has dramatically affected how different sectors work in the world. No single industry will stay as it was before 2020. Education is no different. The pandemic has affected all education levels, mainly tertiary education (Blankenberger \& Williams, 2020). Higher Education Institutions (HEIs) have found themselves confronting an unprecedented and unexpected situation, forcing them to go suddenly online and shift to Emergency Remote Education (Bozkurt et al., 2020). Colleges and Universities in Saudi Arabia are no exception. Three days before the declaration of the World Health Organization (WHO) that Covid-19 is a pandemic on March 11, 2020 (World Health Organization, 2020), Saudi Arabia shut down all schools, colleges, and universities on March 8, 2020 (Saudi Press Agency 2020). The Ministry of Education called all educational institutions to shift immediately to synchronous and asynchronous distance learning. All educational institutions were ordered to use all means of distance learning. According to a UNESCO report, 8,410,264 students were affected in Saudi Arabia, 1,620,491 were in tertiary education (UNESCO, 2020).

Fortunately, almost all Saudi Arabian public universities have ICT infrastructure since the beginning of the millennium (Al-Asmari \& Rabb Khan, 2014) with variation in utilization. After browsing all of the 25 Saudi Arabian public university websites, it was found that each of them has an organizational unit, mainly deanship, and is either specialized in eLearning and Distance Learning (17 universities) or is managing the use of learning management systems and educational platforms, in addition to other information technology (IT) services (eight universities).

All these universities had taken up mainly Blackboard® as the primary learning management system (LMS), if only one, at the time of closure of HEIs in Saudi Arabia (Aljuhney \& Murray, 2016; Al-Nofaie, 2020). All this wherewithal, namely technological and organizational resources, has mitigated the swift switchover to Emergency Remote Learning (ERL), although some obstacles, particularly the bandwidth issues and the Internet speed, especially in remote areas, and availability of laptops and tablets to students (AlHazizi, 2020), have occurred in the way. Other technical problems are linked directly to the Blackboard platform itself, namely the synchronous learning (Alkarani \& Al Thobaity, 2020). This pushed many Saudi universities to adopt other platforms, mainly the video-conferencing platforms, among them were Zoom ${ }^{\circledR}$, Microsoft Teams ${ }^{\circledR}$, Google Meet ${ }^{\circledR}$, and Cisco Webex ${ }^{\circledR}$.

The goal of adoption of other platforms was to diversify the education platforms and devise backup for the learning processes during the ERL, in addition to solve reported connection and bandwidth problems with the only available Blackboard platform. King Saud University in Riyadh, Saudi Arabia, is among the public universities that, in addition to Blackboard, has adopted different platforms, namely Microsoft Teams, Zoom, and Google Meet to deliver synchronous ERT (Figure one). 


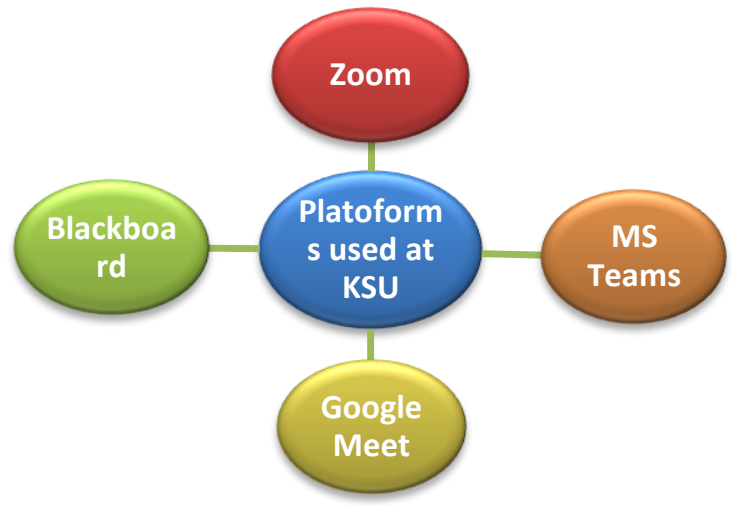

Figure1. Platforms used in Emergency Remote Learning and Teaching at King Saud University

Exploring students' experience with this ERLT during the closure is a critical factor to future implementation of digital learning in HEIs in Saudi Arabia. Undoubtedly, adopting digital learning tools will move from remaining extra-curricular before the pandemic to co-curricular after it is over. The rationale of the present research is to enhance the student-centered learning approaches by obtaining a clear picture of real experiences of parties involved in HEIs in Saudi Arabia, specifically students. Besides, it would give the policymakers a clear picture in planning the inevitable future adoption of digital learning in HEIs in Saudi Arabia. These experiences include variables involved in ERL: the devices used on this ongoing ERL, device and platforms preferences, and gender differences. Hence, this study aims to shed light on these variables. The current study aims to answer the following research questions:

1.What are the devices English major students at the College of Language and Translation in King Saud University use in their ERL?

2. What devices do students prefer in their ERL?

3. What are students' preferences among platforms used in ERLT?

4. Are there any gender differences regarding these variables?

The research objective of the present study is to examine and find out the devices used by English language major students at the College of Languages and Translation in King Saud University, Riyadh, Saudi Arabia during the ERLT and students' device and platform preferences in their ERL. This paper also investigates whether gender differences are the distinctive markers with regard to devices and platforms.

\section{Literature Review}

\section{Defining Terms: Emergency Remote Learning and Teaching (ERLT)}

Different terms have been used to describe the teaching and learning process since the outbreak of the Covid-19 virus. These terms constitute digital learning, e-learning, distance learning, virtual learning, and online learning. Comparing the use of these five terms with the term Covid-19 in Google Scholars, from 2020 until the writing of this paper, it is found that online learning comes first with 9,890 results, followed by e-learning with 7,810, distance learning with 6,280, virtual learning with 2,680, and last of all digital learning with 2,480 marks. Although these terms may have different meanings (Basak, Wotto, \& Belnger, 2018; Moore, Dickinson-Dean \& Galven, 2011), they have been used interchangeably to describe what has 


\section{Arab World English Journal (AWEJ) Special Issue on Covid 19 Challenges April 2021}

been taking place in HEIs during the pandemic. What has been happening in many HEIs worldwide was not more than a sudden and unplanned switchover from face-to-face teaching and learning to ERT and ERL due to the outbreak of the virus. Hodges, Moore, Lockee, Trust, and Bond (2020) stated:

In contrast to experiences that are planned from the beginning and designed to be online, emergency remote teaching (ERT) is a temporary shift of instructional delivery to an alternate delivery mode due to crisis circumstances. It involves the use of fully remote teaching solutions for instruction or education that would otherwise be delivered face-toface (page 7).

Hollweck and Doucet (2020) stressed that the pandemic has hurled educational systems into ERL and ERT. Bozkurt et al. (2020) differentiated between that emergency remote education and planned and purposeful online instructions. Schwartzman (2020) published a paper describing the shift during the Covid-19 outbreak as a sudden shift of course delivery to ERT and ERL rather than intentional online education. And that remote education applied different delivery modes and technological tools as a response to face-to-face instruction. In the Arab World, Hazaea, Bin-Hady, and Toujani (2021) blended English Language Teaching (ELT) and ERT to introduce Emergency Remote English Language Teaching (ERELT) to described the sudden switch from traditional language teaching and learning to virtual environments.

It is a postulate that is a considerable variation in the use of digital learning tools in HEIs for different reasons. These reasons are mainly cultural, economic, and political. Cultural reasons may come first since online learning has been stigmatized as lower quality than face-to-face learning, although findings point towards something entirely different (Hodges, Moore, Lockee, Trust, \& Bond, 2020). Therefore, choosing the precise terms that reflect the situation taking place in other HEIs would help in gaining more insights and making HEIs well planned and prepared for any future sudden closure, whether due to pandemic, war, natural, or ecological crisis or disasters. It will also definitely enhance HEIs' policies of inevitable digital transformation in learning and teaching. Based on that, ERT and ERL are the precise terms describing the teaching and learning processes in all Saudi public universities since the beginning of 2020, except the Saudi Electronic University, since it applies the blended learning approach as its name accordingly implies. Therefore, this study intentionally prefers the term ERL since it reflects the actual situation in the College of Language and Translation at King Saud University during the pandemic.

\section{Students' Experiences during Emergency Remote Learning and Teaching and English Language Teaching and Learning}

Different studies have been conducted throughout the world addressing other elements involved in ERL. Students' experiences in different majors at university levels have been investigated worldwide during the pandemic. Experiences include students' learning methods, readiness, access to synchronous and asynchronous distance learning, electronic learning platforms, acceptance and satisfaction, achievement, faculty preparation, performance, etc.

Almekhlafy (2020) sought to evaluate and assess in his study students' perceptions on the use of language teaching tools and devices during the COVID 19 pandemic and reflected that in the emergency created by the COVID-19 outbreak in Saudi Arabia, ERT tools proved to be a 


\section{Arab World English Journal (AWEJ) Special Issue on Covid 19 Challenges April 2021}

great help in motivating students to continue their education and improve their language acquisition. As the extraordinary situation necessitated the shift to an alternative teaching strategy and resources, students' perceptions also underwent a significantly dramatic change making them more willing to embrace online tools such as Blackboard and the rest. Language teachers, too, recognized the utility of the technological devices as essential teaching resources, and language researchers have been carrying out extensive studies to evaluate the utility of Blackboard and other such teaching tools.

Hazaea et al. (2021) explored the significant and unprecedented computer-generated classroom challenges that Arab English language teachers have confronted during their virtual language lectures and stressed the need to make it more learner-friendly. They proposed remedies to make ELT more learner-friendly since online teaching appears to have become an inevitable part of academic education due to Covid-19, which might continue for a longer time than expected.

Oraif and Elyas (2021) claimed in their work that technology has influenced language teaching in a big way heralding it into a "new phase" (page 7), transforming communication into a digital form empowering students to communicate without "having to travel" (page 7). The researchers uphold the fact that classrooms have been replaced with the virtual and nonlimitative world of technology, which can be significantly modified to respond to the learners' needs and satisfaction. This potential of reaching out to distant geographical spaces has transformed remote teaching into a tremendously welcome opportunity in times of crisis. In terms of language teaching, students have found virtual teaching as easily accessible and suitably tailored to their needs. "The individuals choose what suits them according to their needs, which also affects how the acquired information is manifested to illustrate the knowledge gained. Learners can create various types of content from what they have learned, using videos, images or text, provided that they have the suitable means" (page 10).

In their research work on the willingness of language instructors and learners in Saudi Arabia, with respect to emergency switching over to virtual teaching during COVID-19 crisis, Alqabbani, Almuwais, Benajiba, and Almoayad (2020) maintained that the universities have developed a strong infrastructure and have deployed the application of e-learning as an enduring mode of teaching to realize positive learning outcomes. They suggested that Saudi HEIs must seize the opportunity to increase the number of courses offered online. Another significant finding of their study was that a good majority of students at different Saudi universities have found the virtual environment was useful and effective during the lockdown. Also, they found no difference in students' understanding and accomplishment in the physical classrooms and the emergency virtual classes. On the basis of their research, Alqabbani et al. (2020) asserted that "the growing evidence supporting the effectiveness of e-learning in Saudi universities should encourage more utilization of e-learning or blended modes of teaching in higher education. This will overcome the challenges faced by higher education in Saudi Arabia to accommodate the increasing number of high school graduates and the high workload of instructors" (page 14).

Rahiem (2020) qualitatively investigated the experiences of 80 social science major students at a public university in Indonesia amidst the pandemic and found that they had both positive and negative experiences. Jacque, Ouahabi, and Lequeu (2020) studied the 63 junior and 


\section{Arab World English Journal (AWEJ) Special Issue on Covid 19 Challenges April 2021}

sophomore electrical and electronic engineering students' performance at the University of Tours, France, and discovered that distance learning did not downgrade the learning experience. Saritas and Barutcu (2020) surveyed both graduate and undergraduate university students in Turkey, and results showed that they were ready for online learning during the pandemic. AlNofaie (2020), in comparing synchronous and asynchronous experiences of English language major students in Saudi Arabia, found that students preferred asynchronous environments in their learning during the pandemic.

As for devices used in ERL, Shim and Lee (2020) questioned 393 students in a South Korean university and found laptop was the most preferred device students used in participating in their classes. In India, Muthuprasad, Aiswarya, Aditya, and Jha (2020) found that most of undergraduate agriculture students preferred smartphones in their learning, followed by laptops, then came tablets, and desktops came last. Edelhauser and Lupu-Dima (2020) investigated the devices used by 200 undergraduate and graduate students in Romania and found that most students used smartphones in their online learning during the Covid-19 closure. In Nepal, Nepal, Atreya, Menezes, and Joshi (2020) found that most of 226 medical students used smartphones during the lockdown due to the pandemic. Before the pandemic, Davison and Lazaros (2015) surveyed 20,503 graduate and undergraduate students in Indiana investigating the use of mobile learning devices and they found that laptops came first with $90 \%$, smartphones with $60 \%$, and finally tablets with $45 \%$. They also found that "in every category of digital technology for studies, the laptop was favored" (p. 32).

Regarding the use of electronic platforms during the outbreak of the virus, Jacques, Ouahabi, and Lequeu (2020) stated that many universities all over the world have adopted Zoom due to its ease of use, modern digital ergonomics, and its easy accessibility from different devices like desktops, laptops, or tablets. In Saudi Arabia, Ibrahim et al. (2021) surveyed 340 medical students in King Abdulaziz University in Jeddah concerning their preferences toward the four platforms: Zoom, Blackboard, Hangout, Microsoft Team, and found that Blackboard and Zoom were the most preferred.

Surveying different scientific databases and search engines, it was learned that no single study conducted in Saudi Arabia, up to December 2020, the time of writing this research, has answered the questions posed in this study, particularly addressing students majoring in a foreign language.

\section{Methods \\ Design}

This quantitative descriptive study was a part of a larger project of research on ERLT in foreign language major students in Saudi Arabia. The study aimed to find out the devices used and device preferences by English major students, in addition to platform preferences. The study also statistically explored any gender differences in these variables; the devices and platforms were the dependent variables of the research, whereas the gender was the independent one. To answer the four questions of the study, an online survey was designed using Google forms. Descriptive statistics was applied to answer the questions of the study. 
Arab World English Journal (AWEJ) Special Issue on Covid 19 Challenges April 2021

Devices and Platforms Used in Emergency Remote Learning

Al Shammari

\section{Instruments}

To achieve the objective of this study, a survey was designed to answer its four questions. It consisted of three parts. The first part addressed the demographic data, specifically, gender and age of participants. The second part of the survey was on participant's self-evaluation of computer skills and the possession of devices: namely smartphone, laptops, tablets, and desktops. The last part of the survey was on the use of devices and platforms and participant's preferences. All the questions in the survey were closed-ended questions.

The survey then was posted online through Google forms. All data in this study were collected electronically. Before distributing the survey, it was piloted to several students to ensure the clearance of the questions. The survey was published from December 27, 2020, until January 15, 2021. Data were processed using SPSS. The majority of the responses were collected in the first four days of distribution.

\section{Context of the Study}

The study was conducted at the College of Language and Translation at King Saud University in Riyadh, Saudi Arabia in the fall semester of 2020. COLT offers undergraduate degrees in 10 different foreign languages: English, French, Spanish, German, Russian, Turkish, Japanese, Chinese, Farsi, and Hebrew. It offers only two graduate programs in English and French. All these degrees are available for male students at the Men's campus. Only three undergraduate programs are offered at the Women's campus: English, French, and Chinese. Graduate programs are offered on both campuses. This study was limited to undergraduate English major male and female students on both campuses.

\section{Participants}

The simple random sampling technique was used in the study. The survey distributed to all English major students at different levels and campuses through their university email addresses and WhatsApp accounts. The total number of students who voluntarily participated in the study is 174: 99 male students and 75 female students from different study levels. To answer the study's research questions: namely, to statistically find any gender differences regarding the device use and preferences, and platform used and preferences, a randomly selected sample was taken from male participants to equal the number of female participants. All participants were undergraduate English major students with different levels of study. Table one shows the structure of the respondents.

Table 1. Structure of the respondents

\begin{tabular}{|l|c|c|}
\hline Gender & $\begin{array}{c}\text { Number of } \\
\text { Participants }\end{array}$ & $\begin{array}{c}\text { Selected } \\
\text { Sample }\end{array}$ \\
\hline Male & 99 & 75 \\
\hline Female & 75 & 75 \\
\hline Total & 174 & 150 \\
\hline
\end{tabular}

The selected sample of male participants represented $18 \%$ of the total population of the undergraduate English major students $\mathrm{N}=399$. In contrast, the female participants represented $15 \%$ out of 700 English major students at the undergraduate level at Women's Campus at the end of the year 2020. The average age of all participants was 21.29. 
Regarding the participants' computer skills, the majority of them stated that they have had advanced computer skills (38\%), followed by those who believed they have had average computer skills (31.3), then came those who have had very advanced skills (29.3\%) and finally a percentage of 1.3 stated they possessed weak computer skills. Figure two depicts the participants' computer skills.

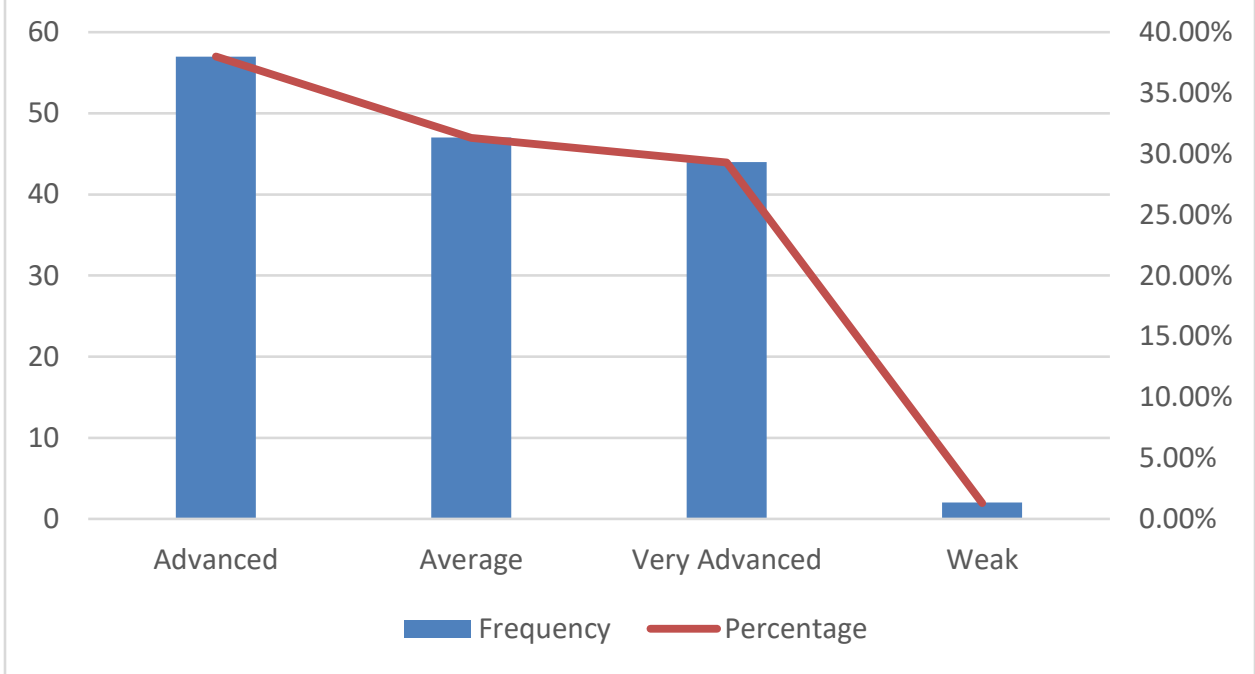

Figure 2. Participants' computer skills

\section{Results}

\section{Devices Used and Preferences}

Before answering the questions concerning devices and preferences, the survey asked participants to list all devices they possessed. The findings of the study showed that all students own smartphones (100\%). Having smartphone and laptop came in second place with 44\%, then owing smartphone, tablets, and laptop in the third place (32\%), followed by those who have had all the four devices; smartphone, tablets, laptops, and desktops (7.3\%), then those with smartphones, laptops, and desktops (6.7\%). Participants having the only smartphones represented $3.3 \%$, and then came both, students who own smartphones and desktops, and smartphones, tablets, and desktops with $2.7 \%$ each. Finally came students with smartphones and tablets with $1.3 \%$. Figure three represents the devices owned and utilized by the students.

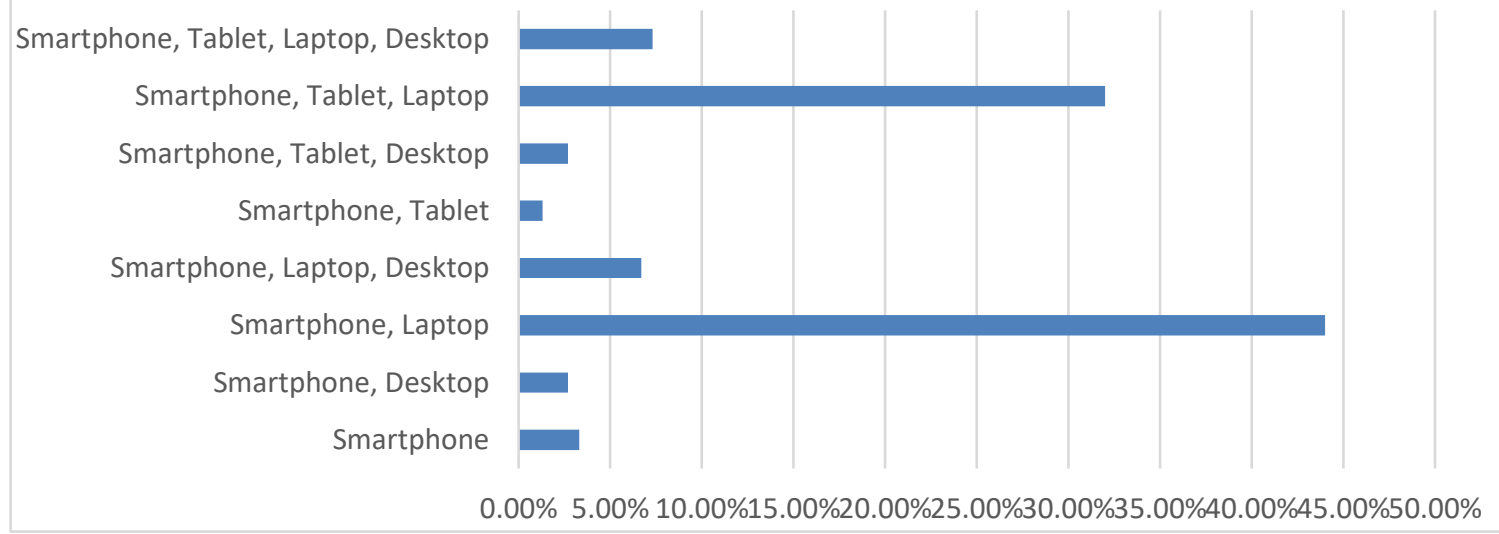

Figure 3. Device ownership of participants 
Arab World English Journal (AWEJ) Special Issue on Covid 19 Challenges April 2021

For the first question of the study concerning the devices used by students in ERL, the results showed that both male and female English major students at COLT used laptop computer $(44.7 \%)$, then smartphone (28\%), followed by desktop computer and tablets with $14.0 \%, 13.3 \%$, respectively. Table two and Figure four show the findings of the research questions.

Table 2. Devices used by participants

\begin{tabular}{|l|c|c|}
\hline \multicolumn{1}{|c|}{ Device } & Frequency & Percentage \\
\hline Desktop & 21 & $14.0 \%$ \\
\hline Smartphone & 42 & $28.0 \%$ \\
\hline Laptop & 67 & $44.7 \%$ \\
\hline Tablet & 20 & $13.3 \%$ \\
\hline Total & 150 & $100 \%$ \\
\hline
\end{tabular}

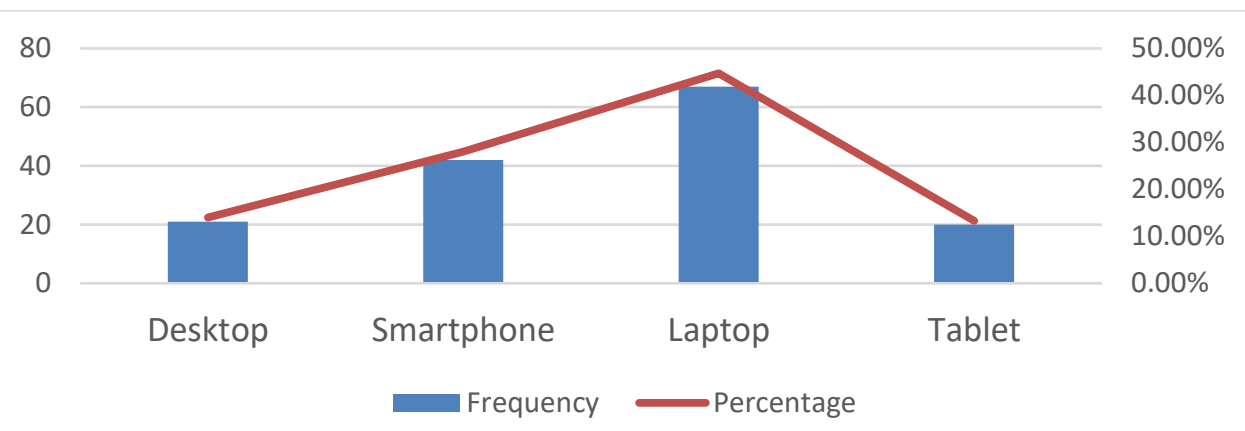

Figure 4. Devices used by participants in ERL

As for the devices the participants preferred and recommended in ERL, the findings (Table three and Figure five) displayed that $60 \%$ of the participants preferred laptop computers in ERL, followed by tablets with $21 \%$, then came desktop computers (14.0\%), and finally smartphones with $4.7 \%$.

Table 3. Device preferences and recommendations

\begin{tabular}{|l|c|c|}
\hline \multicolumn{1}{|c|}{ Device } & Frequency & Percentage \\
\hline Desktop & 21 & $14.0 \%$ \\
\hline Smartphone & 7 & $4.7 \%$ \\
\hline Laptop & 90 & $60.0 \%$ \\
\hline Tablet & 32 & $21.0 \%$ \\
\hline Total & 150 & $100 \%$ \\
\hline
\end{tabular}

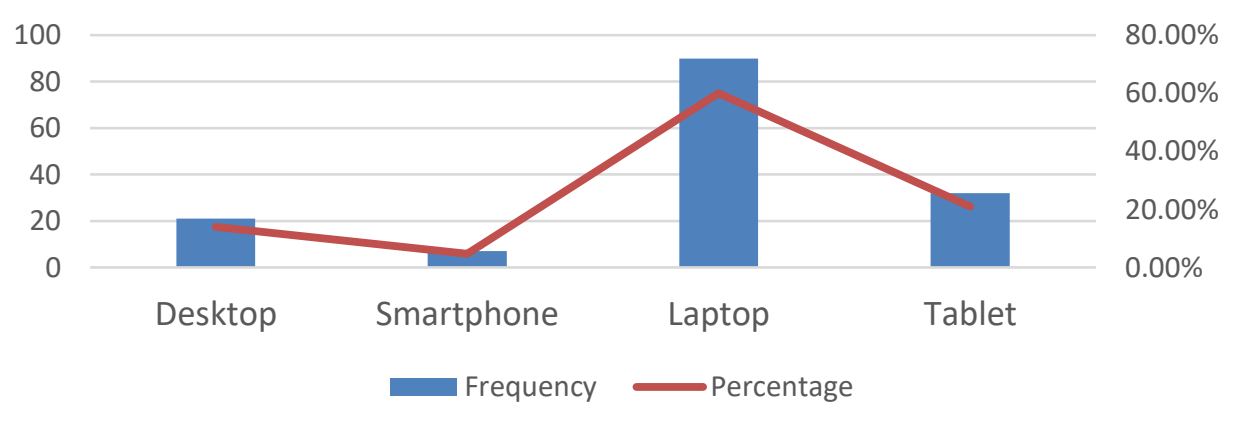

Figure 5. Devices the participants preferred and recommended in ERL 
Arab World English Journal (AWEJ) Special Issue on Covid 19 Challenges April 2021

\section{Platform Preferences}

As mentioned in the introduction, KSU adopted different platforms in ERLT to facilitate the learning processes during the pandemic. Different platforms were used to deliver courses at COLT. The findings showed that $99.3 \%$ of participants had utilized different platforms since the beginning of the closure due to Covid-19. That is, a total of 149 students had used different platforms, and only one participant experienced only one platform, hence excluded. Comparing these platforms and students' preferences, the results revealed that students preferred the Zoom platform (53.3\%), followed by Blackboard (44.3\%), then both MS Teams and Google Meet with $1.3 \%$ and $0.7 \%$, respectively. Figure 6 shows the platforms participants preferred.

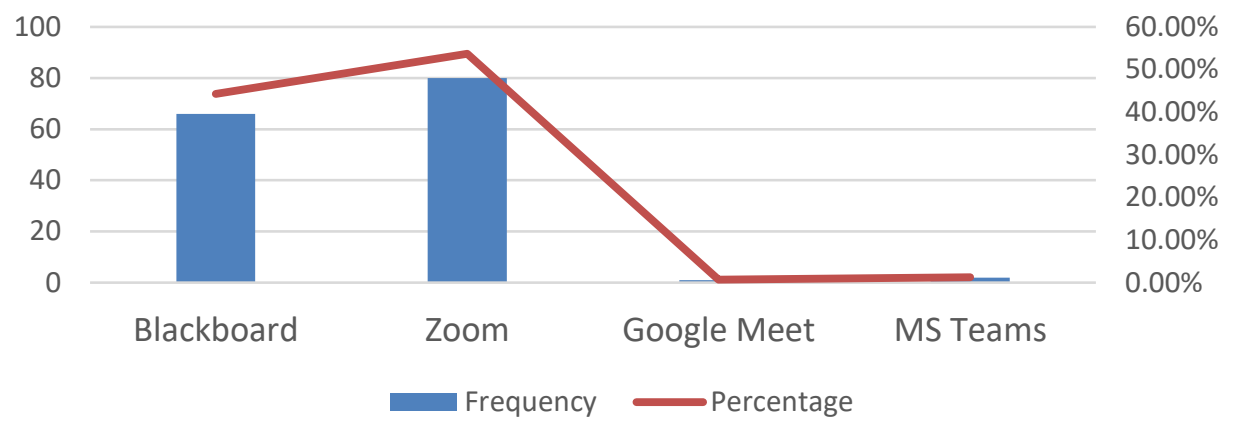

Figure 6. Platforms the participants preferred

\section{Gender Differences in Devices Used and Preferences}

The findings showed a gender difference in devices used and preferences demonstrated regarding the use of devices in ERL, specifically desktop computers and tablets. As for the devices used, the results indicated that male participants used mainly laptop computers in their learning $(36.0 \%)$, followed by smartphones $(32.0 \%)$, then desktop computers with $25.3 \%$, and finally tablets with $6.7 \%$. For women students, laptop computers, as with the men, came first with $53.3 \%$, smartphones (24\%), tablets (20.0\%), and last came desktop computers with $1.3 \%$. Figure seven reveals the gender differences regarding the devices used.

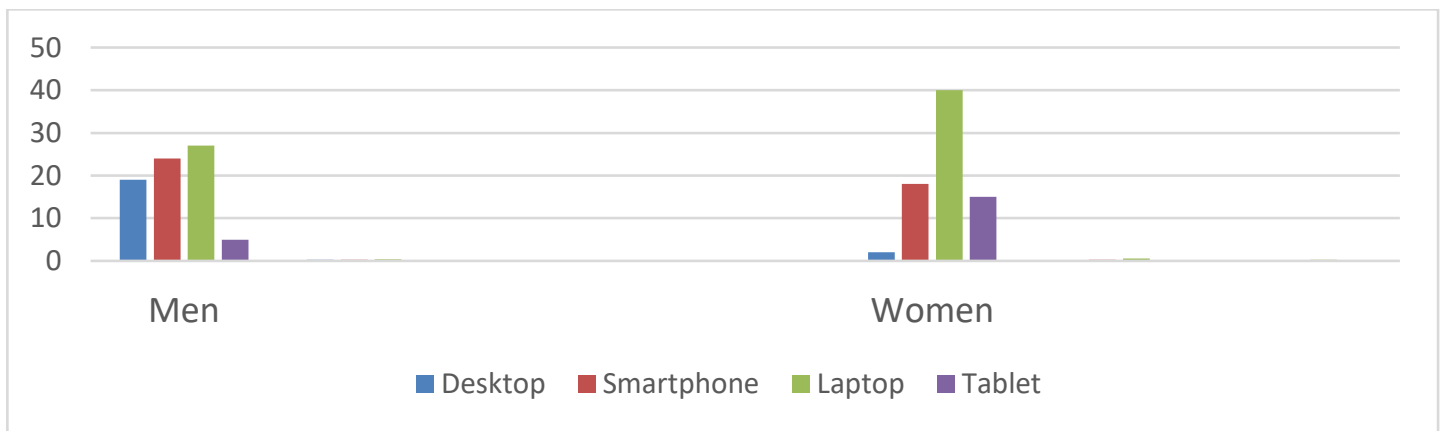

Figure 7. Gender differences in devices used in ERL

As for devices recommended for ERL, there were no gender differences in preferences for laptop computers. The findings showed that both male and female students recommended and preferred using laptops in ERL (60\% each). Gender differences were found in the other device choices. Male students recommended desktop computers in the second place with $26.7 \%$, then tablets with $8 \%$, and finally smartphones with $5.3 \%$. Female students, on the other hand, 
Arab World English Journal (AWEJ) Special Issue on Covid 19 Challenges April 2021

recommended and preferred tablets to be in second place after laptop computers with $34.7 \%$, followed by smartphones (4\%), and at the end came the desktops with $1.3 \%$ (Figure eight).

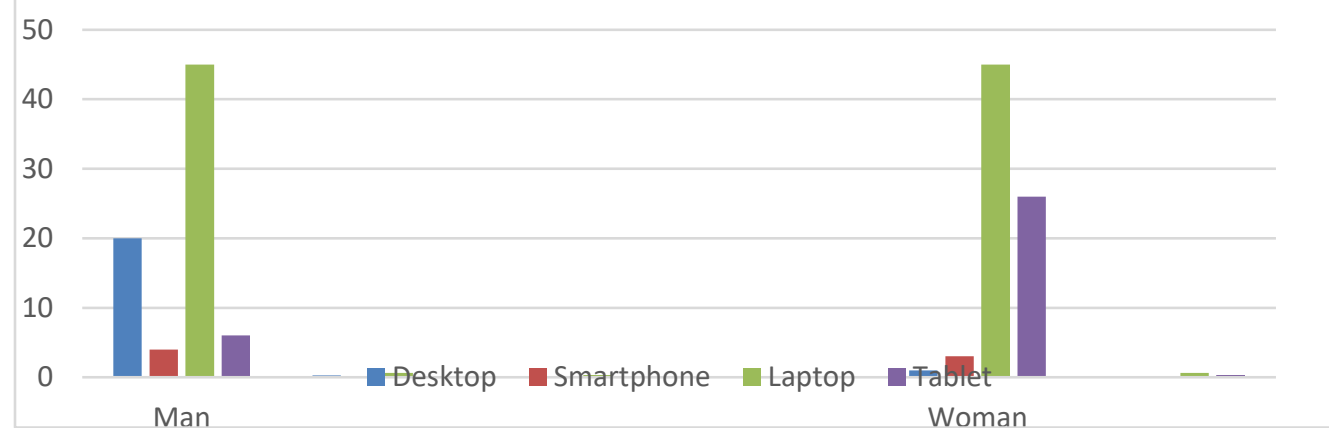

Figure 8. Gender difference in devices recommended

\section{Gender Differences in Platforms}

The analysis of the results showed a gender difference exists in the platforms participants of the study preferred. Male students chose the Zoom platform with $67.6 \%$, followed by Blackboard (29.7\%), and finally Google Meet and MS Teams with 1\% each. For female students, Blackboard came first with $58.7 \%$, followed by Zoom (40\%), then MS Teams with $1.3 \%$, and finally came Google Meet with $0 \%$. Figure nine shows the differences in platform preferences in ERL.

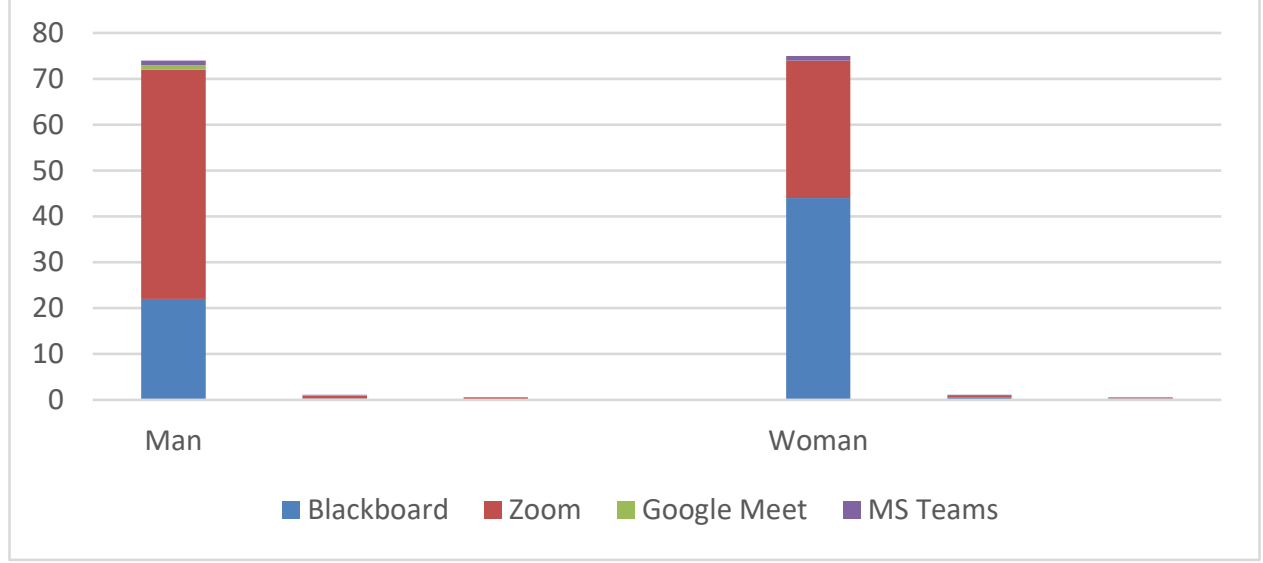

Figure 9. Gender differences in platforms preferences

\section{Discussion}

The study was aimed to shed light on the experiences of English language major students in COLT at KSU in Saudi Arabia during the unprecedented conditions of the present pandemic. It focused on the devices the students used and the devices and platforms they preferred in their ERL. Also, it investigated if there were gender differences in these variables. The present research was initiated after students had experienced ERL for long time to give a clear picture of their preferences since they began using electronic devices for online lessons way back in early March 2020.

The findings of the study showed that laptops came first as the device both men and women students used in their ERL (44.7) compared to smartphones (42\%), desktop computers 


\section{Arab World English Journal (AWEJ) Special Issue on Covid 19 Challenges April 2021}

Devices and Platforms Used in Emergency Remote Learning

Al Shammari

(14\%), and tables (13.3\%). This came in line with the findings of Shim and Lee (2020) and Davison and Lazaros (2015) and in contrary with other studies (Edelhauser \& Lupu-Dima 2020; Muthuprasad, et al., 2020; Nepal et al. 2020). The results also revealed that students at COLT recommended and preferred laptops in their ERL (60\%) in the first place, then came tablets with $21 \%$, followed by desktops with $14 \%$, and finally smartphones with only $4.7 \%$. Participants showed paradoxical positions regarding the devices they used and the ones they preferred and recommended. Although they favored laptops in their ERL, a high percentage (42\%) of them used smartphones, the least preferred device in ERL (4.7\%) among the other three devices. It is not a matter of ownership since the majority of participants possessed laptops. This finding needs further investigation in future researches. These findings indicated that students understand the features offered by laptops over other devices. One of the main features of laptops is their mobility. It is quite correct to say that mobility was also available for the other two devices: smartphones and tablets. Still, laptops overcame those two devices in screen width, comfortableness, and mainly a device for information gathering (Sage, Piazzini, Downey, \& Ewing, 2020). Compared to smartphones, several studies showed that laptops gave students more learning value and engagement other than not representing distractions or being detriments as smartphones (Albó, Hernández-Leo, \& Oliver, 2019; Tossel, Kortum, Shepard, Rahmati, \& Zhong, 2015).

The study also showed that students favored Zoom in the first place $(53.3 \%)$, followed by Blackboard (44.3\%), and finally came MS Teams and Google Meet (1.3\% and 0.7\%, respectively). The findings are similar to those of Ibrahim et al. (2021) concerning the preference for the Zoom platform by students. The results represented an exciting result about the Zoom platform. Zoom, as MS Teams and Google Meet, is new to KSU students, and it just appeared during the pandemic compared with Blackboard, which has been there for more than a decade. Blackboard is a complete learning management system, while Zoom is mainly a videoconferencing platform with some learning tools such as whiteboards, screen sharing, polling, and chatting. There are reasons for favoring Zoom, as Jacques et al. (2020) listed: ease of use and easy accessibility. Further investigations are needed, mainly qualitative studies, to probe more possible causes behind student preferences.

As for gender differences in devices used in ERL, the results indicated that both men and women students mostly used laptops in their learning, followed by smartphones. Differences existed in the use of desktops and tablets. Women used tablets more than men did in their education, and only a small percentage (1.3\%) of them stated that they used desktops. In preferences, no gender differences existed regarding the favorableness of devices. Both genders put laptops first in their recommendation for devices in ERL. A difference existed in other devices: smartphones, desktops, and tablets. Men preferred desktops in the second place, followed by tablets and finally smartphones, while their women counterparts put tablets second, followed by smartphones and eventually desktops. The interesting finding is about smartphones. Although they came second in use by both men and women participants, men put them last in the recommendation, and women preferred them in the third place. Future research should address this point, as mentioned earlier.

The findings of the devices used and preferences demonstrated asserted without doubt that mobile learning (m-learning) was dominant whether in students' use or choices. M-learning 


\section{Arab World English Journal (AWEJ) Special Issue on Covid 19 Challenges April 2021}

is the use of tools like mobiles, laptops, and other such technological devices for language teaching and learning (Sung, Lee, Yang, \& Chang, 2019). In the future, any planned policy addressing digital learning, contrary to emergency shifting to remote learning, should consider m-learning devices, particularly laptops and smartphones.

A gender difference existed in the preferences of platforms. Women favored Blackboard over Zoom whereas their men counterparts were the opposite. MS Teams and Google Meet came with little or even no use. Qualitative studies are recommended here as well for exploring the reasons behind this difference. Future planned integration of digital learning at KSU should consider the features that both platforms offer and not expand the adoption of platforms that do not attract students. Such a thing will save the resources and help in utilizing them in better ways.

\section{Conclusion and Recommendations}

The current unprecedented pandemic has dramatically changed the way the higher education was designed and delivered. Language students are one of the most affected elements of the changes due to the pandemic. Their behaviors and experiences during the pandemic are worth studying and investigating and for insightful analysis and comprehension of the lessons the students have learned in their language classrooms. The goal of the study was to reveal students' experiences with the ERL. It aimed at investigating the devices they used and the platforms they preferred. It sought to examine whether gender differences existed in these two variables.

The results of the study showed that laptops and smartphones were the dominant devices students used in ERL. They also indicated that male and female students preferred laptops in their ERL, and interestingly smartphones came last in students' preferences. As for the platforms used in the ERLT, the findings revealed that the Zoom was the most preferred platform. A gender difference existed in device recommendation, namely desktops and tablets. Another gender difference was found in platform preferences. Female students preferred Blackboard over Zoom.

The findings of this study would help policymakers and decision makers regarding the inevitable integration of digital learning of language and conversion of some courses to be delivered entirely online when the pandemic is over. Further investigations are needed to address the differences in the study and other variables related to students' experiences. The foremost among them is the acceptance of digital learning, the evaluation of teachers' preparedness in the digital environment, and students' acquisition and performance in virtual language learning.
About the Author:
Dr. Mishal H. Al Shammari is an assistant professor at the English Language and Translation Department at King Saud University in Riyadh, Saudi Arabia. His research interests include digital learning, digital transformation in higher education, mobile learning, and academic leadership and change. https://orcid.org/0000-0002-8248-5317 


\section{Arab World English Journal (AWEJ) Special Issue on Covid 19 Challenges April 2021}

Devices and Platforms Used in Emergency Remote Learning

Al Shammari

\section{References}

Al-Asmari, AM., \& Rabb Khan MS (2014). E-learning in Saudi Arabia: Past, present and future, Near and Middle Eastern Journal of Research in Education, 2014(2), 2-11. http://dx.doi.org/10.5339/nmejre.2014.2.

Albó, L., Hernández-Leo, D., \& Oliver, V. (2019). Smartphones or laptops in the collaborative classroom? A study of video-based learning in higher education. Behaviour \& Information Technology, 38(6), 637-649. DOI: 10.1080/0144929X.2018.1549596.

AlHazizi, O. (2020, September 27). The problem of Blackboard and slowness of the Internet troubled university students. Alyoum Newspaper,17271. Retrieved from https://lym.news/a/6279509.

Aljuhney, Y. \& Dr. Murray, L. (2016). A Comparison of the Utilization of E-learning Management Systems in the Republic of Ireland and Kingdom of Saudi Arabia: A Case Study (2015). International Journal on Recent and Innovation Trends in Computing and Communication, 4(2), 01 - 12. https://doi.org/10.17762/ijritcc.v4i2.1751

AlKarani, A. S., \& Al Thobaity, A. (2020). Medical Staff Members' Experiences with Blackboard at Taif University, Saudi Arabia. Journal of multidisciplinary healthcare, 13. 1629-1634. https://doi.org/10.2147/JMDH.S287389.

Almekhlafy, S.S.A. (2020), "Online learning of English language courses via blackboard at Saudi universities in the era of COVID-19: perception and use", PSU Research Review, Vol. ahead-ofprint No. ahead-of-print. https://doi.org/10.1108/PRR-08-2020-0026.

Al-Nofaie, H. (2020). Saudi University Students' Perceptions towards Virtual Education During Covid19 Pandemic: A Case Study of Language Learning via Blackboard. Arab World English Journal, 11 (3), 4-20. DOI: https://dx.doi.org/10.24093/awej/vol11no3.1.

Alqabbani, S., Almuwais, A., Benajiba, N., and Almoayad, F. (2020). Readiness towards emergency shifting to remote learning during COVID-19 pandemic among university instructors. E-Learning and Digital Media. Online First. 1-20. https://doi.org/10.1177/2042753020981651.

Basak, S. K., Wotto, M., and Belanger, P. (2018). E-learning, M-learning and D-learning: Conceptual definition and comparative analysis. E-Learning and Digital Media., Vol. 15(4) 191-216. DOI: $10.1177 / 2042753018785180$.

Blankenberger, B., \& Williams, A. M. (2020) COVID and the impact on higher education: The essential role of integrity and accountability. Administrative Theory \& Praxis, 42(3), 404423, DOI: $10.1080 / 10841806.2020 .1771907$.

Bozkurt, A., Jung, I., Xiao, J., Vladimirschi, V., Schuwer, R., Egorov, G., ... \& Paskevicius, M. (2020). A global outlook to the interruption of education due to COVID-19 pandemic: Navigating in a time of uncertainty and crisis. Asian Journal of Distance Education, 15(1), 1-126.

Davison, C. B., \& Lazaros, E. J. (2015). Adopting mobile technology in the higher education classroom. Journal of Technology Studies, 41(1), 30-39.

Edelhauser, E., \& Lupu-Dima L. (2020). Is Romania Prepared for eLearning during the COVID-19 Pandemic? Sustainability, 12(13), 5438. 1-30. https://doi.org/10.3390/su12135438.

Hazaea, A.N., Bin-Hady, W.R.A., and Toujani, M. M. (2021). Emergency Remote English Language Teaching in the Arab League Countries: Challenges and Remedies. Computer-Assisted Language Learning Electronic Journal (CALL-EJ), 22(1), 201-222.

Hodges, C., Moore, S., Lockee, B., Trust, T., \& Bond, A. (2020). The difference between emergency remote teaching and online learning. Educause review, 27, 1-12.

Hollweck, T., and Doucet, A. (2020), "Pracademics in the pandemic: pedagogies and professionalism", Journal of Professional Capital and Community, 5 (3/4), 295305. https://doi.org/10.1108/JPCC-06-2020-0038.

Ibrahim, N. K. eat al., (2021). Medical students' acceptance and perceptions of e-learning during the Covid-19 closure time in King Abdulaziz University, Jeddah. Journal of Infection and Public Health, 14(1), 17-23. https://doi-org.sdl.idm.oclc.org/10.1016/j.jiph.2020.11.007. 


\section{Arab World English Journal (AWEJ) Special Issue on Covid 19 Challenges April 2021}

Jacques, S., Ouahabi, A., \& Lequeu, T. (2020). Remote Knowledge Acquisition and Assessment During the COVID-19 Pandemic. International Journal of Engineering Pedagogy, 10(6), 120-138. https://doi.org/10.3991/ijep.v10i6.16205.

Moore, J. L., Dickinson-Dean, C., and Galven, K. (2011). e-Learning, online learning, and distance learning environments: Are they the same? The Internet and Higher Education. 14(2). 129-135.

Muthuprasad, T., Aiswarya, S., Aditya, K. S., \& Jha, G. K. (2021). Students' perception and preference for online education in India during COVID -19 pandemic. Social Sciences \& Humanities Open, 3(1). https://doi.org/10.1016/j.ssaho.2020.100101.

Nepal, S., Atreya, A., Menezes, R. G., \& Joshi, R. R. (2020). Students' Perspective on Online Medical Education Amidst the COVID-19 Pandemic in Nepal. Journal of Nepal Health Research Council, 18(3), 551-555. https://doi.org/10.33314/jnhrc.v18i3.2851.

Oraif, I.; Elyas, T. (2021). The Impact of COVID-19 on Learning: Investigating EFL Learners' Engagement in Online Courses in Saudi Arabia. Education Sciences. 2021, 11, 99. 2-19. https://doi.org/10.3390/ educsci110300.

Rahiem, M. D. H. (2020). The Emergency Remote Learning Experience of University Students in Indonesia amidst the COVID-19 Crisis. International Journal of Learning, Teaching and Educational Research, 19(6), 1-26. https://doi.org/10.26803/ijlter.19.6.1.

Sage, K., Piazzini, M., Downey, J. C., \& Ewing, S. (2020). Flip It or Click It: Equivalent Learning of Vocabulary from Paper, Laptop, and Smartphone Flashcards. Journal of Educational Technology Systems, 49(2), 145-169. https://doi.org/10.1177/0047239520943647.

Saritaş, E., \& Barutçu, S. (2020). Digital transformation in education and students' readiness to learn online: A research on Pamukkale University students in the period of pandemic. Internet Uygulamalart ve Yönetimi Dergisi, [Journal of Internet Applications \& Management] 11(1), 522. https://doi-org.sdl.idm.oclc.org/10.34231/iuyd.706397.

Saudi Press Agency. (March 7, 2020). https://arab.news/6g3ve

Schwartzman, R. (2020). Performing pandemic pedagogy. Communication Education, 69(4), 502-517. DOI: $10.1080 / 03634523.2020 .1804602$.

Shim, T. E., \& Lee, S. Y. (2020). College students' experience of emergency remote teaching due to COVID-19. Children and Youth Services Review, 119. https://doiorg.sdl.idm.oclc.org/10.1016/j.childyouth.2020.105578.

Sung, Y. T., Lee, H. Y., Yang, J. M., \& Chang, K. E. (2019). The quality of experimental designs in mobile learning research: A systemic review and self-improvement tool. Educational Research Review, 28, [100279]. https://doi.org/10.1016/j.edurev.2019.05.001.

Tosell, C., Kortum, P., Shepard, C., Rahmati, A., \& Zhong, L. (2015). Exploring smartphone addiction: insights from long-term telemetric behavioral measures. International Journal of Interactive Mobile Technologies, 9(2), 37-43. https://doi.org/10.3991/ ijim.v9i2.4300

UNESCO (2020). Education: from disruption to recovery. Available at https://en.unesco.org/covid19/educationresponse

World Health Organization (2020). Archived: WHO Timeline- COVID-19. Available at https://www.who.int/news/item/27-04-2020-who-timeline---covid-19. 